\title{
Consumer Legal Protection Reviewed from Consumer Protection Law in Consumer Dispute Settlement through Litigation
}

\author{
Muhammad Jarnawansyah ${ }^{1}$, Reza Muhammad Rizqi ${ }^{2}$ \\ ${ }^{1,2}$ Faculty of Economy and Business, Sumbawa University of Technology, West Nusa Tenggara, Indonesia \\ Corresponding Author: Reza Muhammad Rizqi
}

DOI: https://doi.org/10.52403/ijrr.20220121

\begin{abstract}
There is a law called Law Number 8 of 1999 that deals with consumer protection. It says that disputes between consumers and business people can be settled through both litigation and non-litigation channels and that both types of channels can be used to do this. Using the courts to settle consumer disputes is a way to do this. This type of dispute resolution refers to the rules for general courts. So that consumers need to get help from the law to get their rights as consumers. Consumer protection is becoming more and more important as science and technology move faster and faster. This is because the speed of science and technology is what drives the productivity and efficiency of producers for the goods or services they make in order to reach their business goals. As a result of this, either directly or indirectly, the Consumers are the ones who feel the effects of these two things the most. In this case, the consumer protection law says that businesses must give legal protection to their customers, so this shows that businesses must do this. And legal remedies for resolving disputes between customers and business people in the event of a dispute can be used both in court and out of court. In order for a dispute to be resolved through litigation, one party has filed a lawsuit against the other party. However, non-litigation dispute resolution can be done in a number of ways, such as through negotiation, consolidation, mediation, arbitration, and so on.
\end{abstract}

Keywords: Legal Protection, Consumers, Consumer Disputes, Litigation, Laws.

\section{INTRODUCTION}

People who have legally protected get tools that can be both preventive and repressive, both oral and written, to keep them safe from harm. In other words, it can be said that legal protection is a separate picture of how the law works. This picture has the idea that the law is fair, orderly, predictable, beneficial, and peaceful. In order to carry out and protect the law, a place or container is needed. This is called a "means of legal protection." People who work at legal protection facilities can divide them into two types that are easy to understand: preventive legal protection facilities and repressive legal protection facilities. Preventive legal protection allows people who aren't sure about a government decision to say so before it's made official. Preventive legal protection means that government actions are based on freedom of action because, with preventive legal protection, the government is told to be careful when making decisions based on discretion. The goal is to avoid disputes.

In Indonesia, there isn't a law that says how to protect yourself from the law if you want to build a just and prosperous society that is both material and spiritually equal in an era of economic democracy based on Pancasila and the 1945 Constitution. Countries that want to build a just and prosperous world should have policies and rules that are made with the right thought. An era is known as 
"globalization" has come about because of how quickly the economy has grown. Economic activities are now not only spread across regions but have also crossed the borders of a country. It is possible for foreign goods to get into a country quickly, making it easy for people to buy things.

Article 1 of the UUPK says that consumer protection is anything that makes sure that people can get the protection they need. Consumers should be able to buy and use goods and services, and they should be able to have legal certainty when they fight with businesses. People can go to court or not go to court for different reasons. UUPK rules on how to settle disputes without going to court. The Civil Procedure Code also rules on how to settle consumer disputes through litigation. Repressive legal protection is used to settle disputes. In Indonesia, the General Court and Administrative Court handle legal protection in this way. The idea of legal protection against government actions comes from the idea of recognizing and protecting human rights, according to history from the west. This is because the idea of recognizing and protecting human rights is based on restrictions and obligations.

\section{THEORETICAL FRAMEWORK}

This research used the theory of legal protection as a way to look at things. In a country, there must be a relationship between the state and its people. This relationship gives rise to rights and responsibilities, which are both good and bad things. Citizens will be able to get legal help as a right. Giving legal protection is a duty for the state. A state must protect its citizens from legal threats. The 1945 Constitution says that Indonesia is a state of law in paragraph 3: Indonesia is a state of law. So, this means that Indonesia is a country that is based on the rule of law By itself, legal protection is important and a result of a state of law. The state must protect the legal rights of its people.
Legal protection is a way for a country to show respect for its citizens as people. So, learning about the Theory of Legal Protection is very important. People in Indonesia have a right to be protected by the law because of the 1945 Constitution. Article 1 paragraph 3 reads: "Indonesia, a state of law, is based on law." This means that legal protection is an important part of the rule of law. The state must protect the legal rights of its people. Legal protection is a way for a country to show respect for its citizens as people. So, this Legal Protection Theory is very important. The idea of legal protection against government actions comes from the idea of protecting and recognizing people's rights, according to history from the west. This is because the idea of protecting and recognizing people's rights comes from limiting and laying down community obligations. government The most important part of the western concept of human rights is that people have rights and freedoms because of their nature and because they are individuals. These rights and freedoms are above the state and all political groups, and they can't be changed or disputed.

There are many people who think the Western concept of human rights is a concept that only applies to each person. Social rights and economic rights are also added, which makes the Western concept of individualism fade away a little bit more. In Indonesia, the state's ideology and philosophy are called Pancasila, and it is used to figure out how to protect people's rights. The conception of legal protection for the people in the West is based on the concepts of Rechtstaat and "Rule of The Law". By using the Western conception as a framework of thought based on Pancasila, the principle of legal protection in Indonesia is the principle of recognizing and protecting human dignity which is based on Pancasila. The principle of legal protection against government actions is based on and stems from the concept of recognition and protection of human rights because historically in the West, the birth of 
concepts regarding the recognition and protection of human rights is directed at restrictions and laying down community obligations. and government. The UUPK does not provide a limit on what is meant by consumer disputes, where the words "consumer disputes" are found in several parts of the UUPK, namely (Barkatullah, 2018):

a. The mention of consumer disputes as part of a state administrative institution that has dispute resolution between business actors and consumers, in this case, the Consumer Dispute Settlement Agency (BPSK) (Article 1 point 11 UUPK);

b. Settlement of consumer disputes regarding the procedures for dispute resolution is contained in Chapter $\mathrm{X}$ Dispute settlement. This chapter uses the mention of consumer disputes consistently, namely Article 45 paragraph (2) and Article 48 of the UUPK.

Because there is no limit on the definition of consumer disputes in the law, it can be said that what is meant by consumer disputes are disputes between people who use goods or services and people who make them and people who sell them. Consumer disputes can also be thought of as disputes about consumer rights. There is a wide range of topics covered, from civil law to criminal law to how the government works. This is because the term "consumer transaction dispute" is not used because it seems to be more specific than "consumer law dispute," which only deals with civil law issues (Shidarta, 2016).

Articles 45 to 48 of the UUPK are about how to deal with consumer disputes. In the regulation, it is said that people who have been harmed by businesses can sue them through institutions that deal with consumer disputes or through courts in the general judiciary. So, consumer disputes can be settled both in court and out of court. Article 48 of the UUPK says that the first step in a lawsuit is to go to court and ask for a hearing. This is done by referring to
Article 45 of the UUPK, which talks about general courts. Lawsuits can be filed in four ways, such as by an angry consumer or the person who is most concerned. This UUPK has explained how to do this (individual),

According to Miru (2013), the government and non-governmental organizations should use conciliation, which is one way to resolve a dispute that doesn't need to go to court. Conciliation is when an independent person (the conciliator) brings the parties together and helps them communicate with each other. Consumer disputes can also be settled in this way based on the UUPK, but it can also be used in this way as well. Arbitration is a common way to settle a dispute between two people. In this case, a third party will be able to give his own opinion on the dispute that the two people have submitted. In other words, though, the conciliator's opinion isn't just as important as the arbitration award. The next way to settle a consumer dispute without going to court is arbitration. It is based on Presidential Decree 31 of 1981, Law Number 14 of 1970, which was replaced by Law Number 14 of 1980, and again by Law Number 14 of 2004. Law No. 1 of 1950 says that the Supreme Court is a court of the second level for referee decisions. This means that if a case is settled outside of the court on the basis of reconciliation or a referee, it can still happen. In arbitration, the parties agree and have the power to choose an arbitrator; the arbitrator is chosen by the parties; the arbitration award is binding on both sides; the final decision is made by the parties.

\section{DISCUSSION}

Effort Consumers should be more aware, knowledgeable, caring, able, and independent so that they can protect themselves and businesses should be more responsible. Looking at the process of resolving consumer disputes through court proceedings, it looks like there are loopholes that business people can use to get out of their obligations so that consumers stay in a bad position. Under 
Article 4 letter H UUPK, people who have been hurt because the goods they bought don't meet their expectations still have to pay for the loss again because they won't get compensation, compensation, and/or replacement.

If the judge's decision is not carried out by the business actor, the next step is to apply for execution to the Chief Justice. In this process, the consumer must send in an application with data or information about the object to be executed based on the property owner of the business actor. In order to find out what business people own, a process of looking for property owned by business people must be done. Consumers may not be able to find the property of business people that can later be confiscated and executed by the court. This will have an effect on the people who buy things from businesses. If the consumer can't find the property of the business actor, the court can't carry out the execution. If the business actor doesn't have the property executed, the consumer won't get compensation for the loss they had. As long as the business person's property can't be used, the customer has to pay for the loss again. With a system like this, what justice and legal certainty does the consumer get? According to Rawls, who came up with the idea of justice as fairness. This means that justice must be done in a fairway. According to Bahariq (2014), there are two main principles of justice: In order to be fair, you must follow the principle of the best possible justice. According to Bahariq (2014), there are two main principles of justice: In order to be fair, you must follow the principle of the best possible justice. According to Bahariq (2014), there are two main principles of justice, namely:

Formal justice (formal justice, legal justice), applying the same justice for everyone according to the sound of the rules. Here the judge is only a mouthpiece of the law.

Substantive justice, this justice sees justice more than just formal justice, because applying the law means seeking essential justice, and in carrying out this substantive justice it must be supported by a sense of social justice, justice which contains rights and obligations. acceptable to the general public.

From the theory of justice written above, it can be concluded that the law must contain justice, benefit, and legal certainty. The law must provide justice for the whole community, create benefits and legal certainty. Thus, consumers as a society in a state of law should get justice, benefits, and legal certainty, where the legal rules made aim to provide legal certainty in the form of boundaries between the rights and obligations of the parties where these rights and obligations if upheld will create justice. UUPK was made to provide legal certainty and create justice.

Consumer protection guaranteed by the UUPK is the existence of legal certainty for all acquisitions of consumer needs, starting from "living seeds in the mother's womb to the burial place and all needs between the two". Legal certainty includes all efforts based on the law to empower consumers to obtain or determine their choice of goods and/or services they need and to defend or defend their rights if they are harmed by the behavior of business actors providing these consumer needs. This law regulates the implementation of protection for consumers, among others, in the form of protection of consumer rights and methods of settlement if there is a dispute between consumers and business actors.

There needs to be a lot of changes made to the UUPK to make it better for a lot of things, like how consumer disputes are settled. Consumers and business people have an unbalanced relationship when they look at it from their point of view (bargaining position). In the world of business, people who own things and have money to play with them in the market are called "business actors." People who need things are called "consumers." Consumers act as end-users when there is no way for them to make money from transactions with 
business people. This is in line with the goals of the UUPK, which are to protect the interests of consumers that have been ignored so far. In practice, it hasn't worked very well, and this is why it's important to protect consumers. Government policies to protect consumers haven't had a big impact and are only limited to the level of regulations that haven't worked in the field. In the field, people are still being exploited. This paper gives an overview and gives ideas on how to change the UUPK as soon as possible so that consumers don't lose money because of the actions of businesses.

In both public and private disputes, the courts are used to settle disagreements. For disputes that put more emphasis on legal certainty, the best way to settle them is to go to court. So, if you want to build good relationships, like in the business world, the best way to settle a dispute is through nonlitigation in the form of reconciliation or mediation. If you want more legal certainty, you should try to settle the dispute through litigation, which ideally gives both sides more legal certainty because the judge's decision, which has legal force, stays legal. binding means there is no other legal remedy and must be done by the parties. It must be done. Despite what you might think, this isn't true. The consumer or plaintiff (the party that wins) doesn't know for sure what their rights are, as they are outlined in Article 4 of the UUPK. If the decision is not made voluntarily, then a request for execution must be made. The right to compensation can't be realized if the decision is not made voluntarily. People who win a court case have to make a request for execution with data or information about what they want the judge to do before the process can start. To make sure that if the winner (the consumer) can't find the property of the loser, the consumer only gets a decision with no way to follow through with the decision. This hurts people's sense of justice, where the heart of the law is to make sure everyone is treated fairly and that the law is clear for everyone in the community.
Efforts by the law to protect consumers' rights, such as the right to comfort, security, and safety when buying goods and services. It is important that people pick goods and services that are within their budget and meet their needs. They also need to know what they can expect from the goods and services as well as what they can expect to happen if they buy them. For goods and/or services used, get help, advocacy, and help with consumer protection issues, as well as guidance and consumer education. There is no discrimination when people are treated or served. As well as to get compensation, compensation, and/or a new one.

\section{CONCLUSION}

Based on the discussion that has been stated in previous chapters, the following conclusions can be drawn:

1. Legal protection for consumers is a must given by business actors to consumers because in this case it has been regulated in the consumer protection law. Legal protection in the form of the realization of consumer rights must be upheld because it relates to the principle of legal certainty in which the UUPK has regulated the protection of consumer rights and obligations of business actors.

2. Legal remedies for dispute resolution between customers and business actors in the event of a dispute can be carried out by litigation or non-litigation dispute resolution. Dispute resolution through litigation is based on a lawsuit filed by one of the parties. However, nonlitigation dispute resolution can be done in several ways, for example in negotiation, consolidation, mediation, and arbitration.

3. Concrete steps to harmonize the laws and regulations governing consumer protection with the rules regarding the settlement of consumer disputes through litigation that are guided by the provisions and regulations of the law so that they do not have weaknesses to be exploited by one party that could injure 
Muhammad Jarnawansyah et.al. Consumer legal protection reviewed from consumer protection law in consumer dispute settlement through litigation.

the rights of the other party so that it does not create justice and there is no legal certainty for the parties. If harmonization is not able to be implemented, then the government needs to make a comprehensive statutory regulation starting from preventive arrangements (before there is a violation) to repressive arrangements (after there is a violation) so that one rule is only used to regulate the matter so that if there is a dispute.

\section{Acknowledgement: None}

\section{Conflict of Interest: None}

\section{REFERENCES}

1. Ahmadi Miru and Sutarman Yodo. 2017. Consumer Protection Law, (Jakarta: Raja Grafindo Persada.

2. Barkatullah, Abdul Halim, 2018, Consumer Protection Law Theoretical Studies and Development of Thought, Nusa Media, Bandung.

3. Dwiyatmi, Sri Harini, 2016. Introduction to Indonesian Law, Ghalia Indonesia, Bogor.
4. Janus Sidabalok 2016. Consumer Protection Law in Indonesia. Bandung: PT. Image of Aditya Bakti.

5. Miru, Ahmadi and Yodo, Sutarman, 2011, Consumer Protection Law, RajaGrafindo Persada, Jakarta.

6. Ribalsyah, Julias Bahariq, 2014. The Relevance of Law Number 8 of 1999 With LawCivil Procedure in Settlement of Consumer Disputes (Case Study Case Register Number: 732 K/PDT/2007). JournalSemarang State University, Semarang.

7. Shidarta, 2016, Indonesian Consumer Protection Law, Grasindo, Jakarta.

8. Sudikno Mertokusumo.2015. Knowing the Law An Introduction, Cet. Second, (Yogyakarta: Liberty, 2015)

9. Law No. 8 of 1999 concerning Consumer Protection

How to cite this article: Muhammad Jarnawansyah, Reza Muhammad Rizqi. Consumer legal protection reviewed from consumer protection law in consumer dispute settlement through litigation. International Journal of Research and Review. 2022; 9(1): 161-166. DOI: https://doi.org/10.52403/ijrr. 20220121 